\title{
Formation of Engineers' Professional Orientation at Technical Higher Educational Institutions
}

\author{
Elena Mikhaylovna Kargina \\ PhD in Pedagogical Science, Penza State University of Architecture and Construction, Russia \\ kargina-elena@mail.ru
}

\section{Doi:10.5901/mjss.2015.v6n5s1p117}

\section{Abstract}

The orientation acts as the system forming quality of the personality defining its psychological features. The goals and motives of human activities, its subjective attitudes towards different aspects of reality are expressed in an orientation. The article is devoted to the formation analysis of engineers' professional orientation at technical higher educational institutions. Results of experimental data monitoring on professional orientation formation in the University Educational Complex are presented.

Keywords: professional orientation, future specialist, technical higher educational institution, university educational complex, differential and diagnostic questionnaire, sphere of interests

\section{Introduction}

Professional orientation becomes more and more important in a globalizing and competitive world. Professional orientation does not only provide information on education and professional training opportunities, it not only shows ways into employment, but also assists in entering the labor market (OECD and European Commission, 2004; UNESCO, \& ILO, 2002).

S.L. Rubenstein defines the orientation problem as a question of dynamic tendencies which determine activity as motives, in turn, being determined by its purposes and tasks (Rubenstein, S.L., 2000). Professional orientation of engineers' assumes the understanding and internal acceptance of the professional activity purposes and problems, interests, ideals, belief, views. Person's knowledge of the career orientations will allow clearly defining in the professional preferences for the selection of faculty and future profession.

\section{Experimental Study}

Experiment was made on the basis of versatile educational complex (experimental group) and in establishments of the regional education system (control group) (Kargina, E.M., 2015).

Main objective of University Educational Complex of Penza State University of Architecture and Construction is association of scientific, intellectual and material potential of educational, information and other organizations for creation of integration regional and branch system of continuous education, improvement of specialists' training quality.

The main tasks of University Educational Complex are:

- development of regional components of the state educational standards for general and professional education;

- effective use of material, scientific, educational and information bases by members of University educational complex;

- creation of educational programs, grants, textbooks for scientific and methodical ensuring the disciplines included in regional and branch components of the state educational standards;

- creation on the basis of University Educational Complex of regional, federal and international system of the academic information;

- assistance in formation and development of the investment innovative programs in education providing high quality of training, continuity of the general and professional education, development of branch production forces of the region;

- assistance to educational, production and other institutions and organizations in formation of personnel, scientific and methodical capacity of Penza region on the basis of additional professional education faculty; 
- ensuring purposeful orientation of the general and professional education to demand from the personality, various social and professional groups, market economy of Penza region;

- elimination of disproportion between the volume of training and demand for them in branch labor market.

The structure of University Educational Complex management includes the following institutes:

- conference of University Educational Complex;

- board of trustees of University Educational Complex;

- academic council (presidium) of University Educational Complex;

- scientific and methodical council of University educational complex.

Creation of University Educational Complex promotes formation of uniform educational space, provides the high level of continuity between educational institutions.

The professional orientation assessment is made on the basis of the activity preferences analysis. The differential and diagnostic questionnaire is used for this purpose (Yeliseyev, O.P., 2002).

Analyzing results of this questionnaire, it is possible to draw conclusions:

- about professional plan existence and degree of its formation (it is possible to consider the professional plan created when the profession is chosen, ways of its receiving are thought over and there is a confidence in choice correctness);

- about sensibleness of profession choice (it is possible to consider a choice realized in case it is made taking into account interests and the previous experience of the personality).

The method is based on the scheme of professions classification. According to this scheme all professions can be divided into five groups on the labor object: «the person - the nature», «the person - the technique», «the person - the person», «the person - the sign system», «the person - the art image».

The analysis of research results shows that in senior students' control group (traditional educational institutions) at the Penza State University of Architecture and Construction is observed the following hierarchy of the leading kinds of activity:

1 position - «the person - the person» (on average -6.9 of 8 possible points). The preference is given to such statements as: «To help sick people», «To bring goods to the consumer (to advertise, to sell)», «To train contemporaries (or younger) in performance of any actions (labor, educational, sports)», «To report, explain to people data necessary to them», «To investigate quarrels, disputes between people, to convince, explain, encourage, punish», etc.

2 position - «the person - the sign system» (on average -5.8 points from 8 possible points). Such positions are chosen: «To make tables, schemes, computer programs», «To discuss popular scientific books, articles», «To look for and correct errors in texts, tables, drawings», «To carry out calculations», etc.

3 position - «the person - the technique» (on average -3.6 of 8 possible points). Positive attitudes are expressed to such phrases as: «To service cars, devices (to watch, regulate)», «To process materials (fabric, metal, plastic)», «To operate any cargo, lifting vehicle (a crane, a tractor, a locomotive)», «To design, project new types of industrial products (cars, clothes, houses, food)», «To carry out installation of the building or assembling of cars, devices», «To produce according to drawings of details, products (cars, clothes, to build buildings)», etc.

4 position - «the person - the art image» (on average -3.4 points from 8). Such statements are preferable: «To watch quality of book illustrations, posters, art cards», «To discuss art books», «To copy drawings, images, to tune musical instruments», «To organize exhibitions, shop windows, to participate in preparation of plays, concerts», «To observe, study work of amateur performances circles», «To paint walls of rooms, worktops of products», «To perform on stage, to participate in concerts», etc.

5 position - «the person - the nature» (on average -2.4 points from 8 possible). Such phrases are allocated: «To look after animals», «To watch a state, development of plants», «To treat animals», «To grove up new plant varieties», «To observe, study life of microbes», «To do laboratory analyses in hospital», «To fight with diseases of plants», etc.

Analyzing this sequence, it should be noted that, going to technical high school, entrants of control group give preference not to computing operations or drawing up schemes and programs («the person - the sign system»), not to designing and operating of mechanisms («the person - the technique»), but to relationship with people («the person - the person»). It proves accident of technical specialty choice.

The results received when studied the experimental group of senior students are given in Table 1. 
Table 1: The interests hierarchy in the experimental group of senior students

\begin{tabular}{|c|l|c|c|}
\hline № & The interests hierarchy & Average result & Maximum possible result \\
\hline 1 & the person - the sign system & 7.1 & 8 \\
\hline 2 & the person - the technique & 5.5 & 8 \\
\hline 3 & the person - the person & 4.3 & 8 \\
\hline 4 & the person - the art image & 3.1 & 8 \\
\hline 5 & the person - the nature & 1.8 & 8 \\
\hline
\end{tabular}

The first position of interests is taken by «the person - the sign system» that is caused by exact disciplines prevalence in the training program of profile technical classes at complex schools. Students of experimental group show interest in drawing up schemes, tables, programs, in carrying out calculations. It corresponds to technical specialties specifics at the Penza State University of Architecture and Construction. «The person - the technique» is on the second place in the hierarchy of interests. The spheres «the person - the art image», «the person - the nature» attract less interest.

The preferences analysis by gender in the experimental group indicated the choice of the sphere «the person - the technique» mainly by young men (Figure 1).

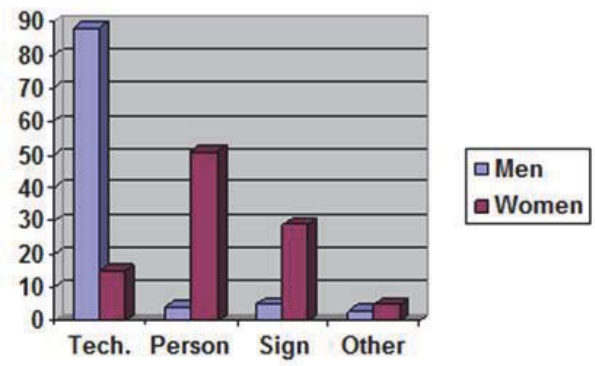

Figure 1. The preferences analysis by gender in the experimental group

The specification of a professional orientation is promoted by the technique "Questionnaire of professional readiness» developed by L.N. Kabardova (Practical Studies on the General, Experimental and Applied Psychology, 2003). The author defines professional readiness as the subjective condition of the personality meaning desire and ability to be engaged in this type of professional activity. The questionnaire is based on a self-assessment by the person of the tendencies and opportunities. Results of this research confirm results of the differential and diagnostic questionnaire. The leading kind of activity in the control group is «the person - the person», in the experimental group - «the person - the sign system». Skills and experience in these kinds of activities are estimated also by most.

The differential and diagnostic questionnaire was offered the graduates of the Penza State University of Architecture and Construction (4-5 courses) and young specialists working 3-5 years (Table 2).

Table 2: Results of the students' testing by means of the differential and diagnostic questionnaire

\begin{tabular}{|c|c|c|c|c|}
\hline \multirow{2}{*}{ № } & \multicolumn{2}{|c|}{ Graduates } & \multicolumn{2}{|c|}{ Young specialists } \\
\hline & Control group & Experimental group & Control group & Experimental group \\
\hline 1 & the person - the sign system & the person - the technique & the person - the technique & the person - the technique \\
\hline 2 & the person - the technique & the person - the sign system & the person - the sign system & the person - the sign system \\
\hline 3 & the person - the person & the person - the person & the person - the person & the person - the person \\
\hline 4 & the person - the art image & the person - the art image & the person - the art image & the person - the art image \\
\hline 5 & the person - the nature & the person - the nature & the person - the nature & the person - the nature \\
\hline
\end{tabular}

In control group of the Penza State University of Architecture and Construction graduates the sphere «the person - the sign system» came out on top. It displaced the sphere «the person - the person» prevailing at senior students on the third place. Students of control group, being trained at the technical higher education institution carried out calculations, made schemes and tables. The next place in hierarchy is taken by the sphere «the person - the technique». It trains 
students in design, production of new mechanisms.

In experimental group of the Penza State University of Architecture and Construction graduates the sphere «the person - the technique» came out on top. It displaced the sphere «the person - the sign system» on the second place. Having studied at higher education institution 4-5 years, having passed some work practice at the enterprises and in the organizations graduates show more interest in a technical, practical sphere of future profession, than in theoretical calculations and drawing up schemes.

In the category of the young specialists who graduated from the Penza State University of Architecture and Construction and worked in the specialty 3-5 years in experimental group there were no changes in hierarchy of interests.

The sphere «the person - the technique» has taken a leading position in the hierarchy of young specialists' interests in the control group. It is connected with direct work of young specialists in practical professional activity with equipment.

The interests hierarchy in control group is identical to interests hierarchy in experimental group at the final research stage.

\section{Conclusions}

Professional orientation is an important element of active life-long learning and a key issue to be integrated in governments' labor market policies (Kayser, J. \& Hassler, l., 2013).

The received sequence of preferences in experimental group is the proof of profession choice sensibleness. Students of the University educational complex chose future profession taking into account interests and the previous experience of the personality, with understanding of profession choice adequate motives. Thus it is possible to draw a conclusion that students of a university complex have a professional plan with high degree of its formation (Kargina, E.M., 2007).

Only one change («the person - the sign system» « «the person - the technique») occurred in interests hierarchy of three allocated categories: senior students of the Penza State University of Architecture and Construction, graduates (4-5 courses), young specialists of experimental group. It testifies that the profession was chosen before entering the Penza State University of Architecture and Construction. Ways of profession receiving were thought over. There was a strong confidence in choice correctness.

There were a number of changes in control groups of all three allocated studied categories. The initial priority of the sphere «the person - the person» testifies to humanitarian interests of technical high school entrants. Students of traditional educational institutions don't have professional motivation. Their choice of future profession is casual. Changes in graduates' interests hierarchy happened only on final years: the leading positions were taken by the spheres «the person - the sign system» and «the person - the technique».

Having felt need of practical application of theoretical knowledge and experience, young specialists of control group put on the first place the sphere «the person - the technique». Thanks to competent professional motivation production received young qualified engineers, interested in the profession.

Good career guidance and placement support not only helps enterprises to find much-needed skilled personnel, it not only helps people to apply their talents and skills in the best of opportunities and smoothen their school-to-work transition, it also contributes to the reduction of social problems by providing people with better and faster income opportunities and integrate many unemployed youth in the labor market (Kayser, J. \& Hassler, l., 2013).

\section{References}

Yeliseyev, O.P. (2002). Practicum on Psychology of the Personality, St. Petersburg, 214

Practical Studies on the General, Experimental and Applied Psychology (2003) / V.D. Balin, V.K. Gerbachevsky, etc., St. Petersburg, 379.

Kargina, E.M. (2007). Theoretical and methodological bases of pedagogical process profiling in technical higher education institutions, Monograph, Moscow.

Kargina, E.M. (2015). Efficiency of Training of Engineers in the Conditions of Educational Environment Profiling of Technical Higher Education. Contemporary Engineering Sciences, Vol. 8, 2015, no. 2, 49-56. http://dx.doi.org/10.12988/ces.2015.412269.

Kargina, E.M. (2015). The Analysis of Educational Projects for Continuous Training of Engineers at Various Stages of the Profile Educational Environment. Contemporary Engineering Sciences, Vol.8, 2015, no.7, 323-328. http://dx.doi.org/10.12988/ces.2015. 5226.

Kayser, J. \& Hassler, I. (2013). Interregional study. Professional Orientation and Job Placement, Bfz gGmbH International Division.

OECD and European Commission (2004): Career Guidance, A handbook for policy makers. Paris, 10. 
Rubenstein, S.L. (2000). Fundamentals of the general psychology, St. Petersburg, 191.

UNESCO, \& ILO (2002). Technical and vocational education for the twenty - first century: ILO and UNESCO recommendations, Paris: UNESCO and Geneva: ILO. 